Article

\title{
The Political Economy of the EU Approach to the Rohingya Crisis in Myanmar
}

\author{
Arlo Poletti * and Daniela Sicurelli \\ Department of Sociology and Social Research, University of Trento, Italy \\ * Corresponding author (arlo.poletti@unitn.it)
}

Submitted: 9 July 2021 | Accepted: 22 September 2021 | Published: 26 January 2022

\begin{abstract}
European institutions have repeatedly represented the EU as an actor that can use the attractiveness of its market to promote human rights internationally. From this perspective, EU trade sanctions represent a hard power tool to push the government of states accused of major human rights violations to abide by international law. In its reaction to the Rohingya crisis in 2018, despite the European Parliament's call for the lifting of Myanmar's trade preferences, the Council of the EU stated that it would rather tackle the problem by taking a "constructive approach" based on dialogue. We provide a political-economy explanation of this choice, making a plausible case that the political pressures from European importers and exporters, not to jeopardise trade relations with Myanmar, prevailed over the demands of European protectionist groups and NGOs advocating a tougher position. The firms interested in maintaining preferential trade relations with Myanmar were primarily motivated by a desire to avoid a disruption of trade and investment links within global value chains (GVCs) so that they could continue competing with Chinese enterprises.
\end{abstract}

\section{Keywords}

European Union; generalised system of preferences; human rights; Myanmar; sanctions; trade

\section{Issue}

This article is part of the issue "Beyond Foreign Policy? EU Sanctions at the Intersection of Development, Trade, and CFSP" edited by Katharina Meissner (University of Vienna) and Clara Portela (University of Valencia).

(C) 2022 by the author(s); licensee Cogitatio (Lisbon, Portugal). This article is licensed under a Creative Commons Attribution 4.0 International License (CC BY).

\section{Introduction}

The EU has actively promoted human rights, labour rights, and democracy in Myanmar since the 1990s. More specifically, in 1996, following the imposition of sanctions in the framework of the Common Foreign and Security Policy, it opted (for the first time in the history of the EU external relations) to suspend the generalised system of preferences (GSP) in relation to the Asian country. Such a suspension was based on the accusation that the military junta supported forced labour. The GSP scheme is an exception to the non-discrimination rule under WTO law which offers developing countries unilateral preferential access to the EU market. It can be temporarily suspended in case of serious and persistent violations of core human and labour rights as defined in the Geneva Conventions and the International Labour Organisation (ILO) Convention. As Portela and Orbie (2014, p. 63) argue, "the stick and carrot conditionality of the EU's GSP system constitutes the 'flagship' of trade initiatives aimed at supporting sustainable development and human rights."

After the escalation of the Rohingya crisis in 2017 and the related accusations of the junta of being responsible for genocide, the idea of implementing such a sanction entered once again the agenda of the European institutions. The coverage of the crisis in the European media and its relevance for public opinion made human rights promotion in Myanmar a priority for European external relations. In this case, though, the EU opted instead for a milder approach than in the mid-1990s. While the Council did consider the possibility of once 
again suspending the GSP in support of targeted sanctions against the Burmese military, it finally adopted a softer position and refrained from doing so.

We investigate the factors driving this variation over time in the relations between the EU and Myanmar, taking an original perspective that focuses on the preferences and patterns of political mobilisation of relevant domestic constituencies. More specifically, we contend that this variation can be accounted for by explicitly discussing how the integration of the EU economy within so-called global value chains (GVCs) affects the preferences and patterns of political mobilisation of organised trade-related interests and feeds into the policymaking process relating to economic sanctions.

The integration of the EU economy in GVCs means an increasing number of firms rely on imports of finished products or intermediate inputs produced in developing countries with lower labour costs. These importdependent firms can be expected to oppose the adoption of trade policy decisions likely to increase their imports' variable costs. When the EU adopts trade policy decisions regarding developing countries with which it is highly integrated into GVCs, these import-dependent firms can be expected to mobilise politically to avoid the adoption of policies that will have negative distributive consequences for them (Eckhardt \& Poletti, 2016). Since the decision to suspend the GSP scheme in cases of human or labour rights violations is a policy choice that ultimately affects key domestic trade-related constituencies in the EU, this implies that firms integrated into GVCs could be expected to oppose the suspension of the GSP and increase the political weight of the domestic coalition supporting this policy stance.

We leverage, and show the plausibility of, this line of reasoning in the context of a longitudinal case study of EU-Myanmar relations spanning the period between 1997 and 2017. More specifically, we draw on processrelated evidence to make a plausible case that variation in the degree of political mobilisation of importdependent firms within the EU across the two time periods can account for the observed variation in the EU's use of economic sanctions. In addition, as a further probe, we also briefly consider the case of EU relations with Cambodia.

\section{Existing Explanations}

The literature on EU sanctions suggests several potential explanations for why the EU changed its approach to economic sanctions towards Myanmar over the course of a decade. Portela and Orbie (2014), for instance, analysed the decision to suspend GSP towards Myanmar in 1996, noting that it was coherent with the Common Foreign and Security Policy sanctions that had existed prior to the decision-making process on GSP sanctions and that it came about after the ILO had set up a commission of inquiry condemning the country. While this analysis sheds important light on the inter-institutional dynam- ics that underpinned the decision to impose sanctions against Myanmar in 1997, it is unlikely to offer a plausible account for the observed variation over time that we are interested in here. For one, CFSP sanctions have never been completely lifted in Myanmar and were still, at least partly, in place in 2017 when the option of suspending the GSP scheme was being considered. Indeed, in response to the political developments in Myanmar in April 2013, the EU lifted the bulk of CFSP sanctions against Myanmar but retained the arms embargo, which has been extended every year since 2013. In 2018, the EU Council confirmed the relevance of the existing embargo and expanded the restrictive measures on Myanmar with a prohibition on the export of dual-use goods, restrictions on the export of equipment for monitoring communications that might be used for internal repression, and on military training and military cooperation (SIPRI, 2021). In addition, differences in inter-institutional dynamics in the two time periods do not necessarily explain why the EU did impose commercial sanctions in reaction to forced labour accusations, and it did not when arguably greater concerns emerged concerning allegations about the military's involvement in genocide.

Others suggest that observed changes in the EU's strategy towards Myanmar may be related to long-term learning processes about the (in)effectiveness of economic sanctions. For instance, Giumelli and Ivan (2013) argue that the EU has shown a learning curve in sanctions, shifting from comprehensive embargoes to sanctions which target individuals due to the realisation of the ineffectiveness of economic sanctions in bringing about the desired policy changes. This shift also reflects the need to factor in humanitarian consequences and the pressure of domestic public opinion on policy choices. While this argument highlights important general trends in the EU's approach towards economic sanctions, it remains unclear whether it can illuminate the dynamics that underpin the evolution of the EU's approach towards Myanmar. For instance, the impact of EU economic sanctions towards Myanmar imposed from 1996 to 2013 is multifaceted. After all, one may conclude that, despite their impact on workers in the economic sectors which export to the $\mathrm{EU}$, the isolation of the country from the international community might have indirectly contributed to the-albeit weak-transition of the country to a semi-democracy from 2015 to January 2021. Thus, one may wonder whether conditions for a policy learning process were actually in place in the particular context of the EU-Myanmar dyadic relationship.

Similarly focusing on the role of norms, Staunton and Ralph (2020) explain the EU's timid approach to the Rohingya case in 2017 as a result of the fact that the grafting of atrocity prevention onto related yet distinct norms contributed to the threat of genocide being underestimated and a misplaced faith in the ability of democratic transition to prevent atrocities. This article is an important contribution that sheds light on how abstractly aligned norms clashed in practice to produce 
a particular trajectory of EU engagement with Myanmar. However, this contribution, too, leaves a number of questions open. More prominently, it remains unclear what the role of key societal stakeholders in the EU might have been in shaping the complex relationship between different norms.

In general, existing explanations overlook the impact of the dynamics of political mobilisation of relevant organised societal interests in shaping the evolving EU's attitude towards Myanmar. This is an important oversight. As Giumelli (2017) clearly shows, the imposition of economic sanctions generates stark distributional consequences not only for the target but also for the sender. This means that the decision-making process underpinning the decision to impose a sanction in the EU, as in any other state, is likely to be affected by the preferences and patterns of political mobilisation of the domestic (potential) winners and (potential) losers of such a policy choice. In turn, this implies that it is a priori plausible that observed changes in the EU's approach towards economic sanctions might be, at least in part, influenced by structural transformations determining changes over time in the domestic politics underlying EU sanctions policy. Therefore, we seek to complement the existing literature by developing an international political economy (IPE) explanation of why the EU imposed commercial sanctions on Myanmar in 1996 and opted not to impose them two decades later.

\section{Argument}

Traditional models of trade policy tend to conceive of policymakers as transmission belts for the demands of organised domestic societal groups. According to this view, EU policymakers mostly react to the demands of export-oriented sectors wishing to see better access to foreign markets and import-competing sectors wishing to reduce exposure to foreign competition domestically (Poletti et al., 2021). Although the EU's willingness to commit to trade liberalisation ultimately depends on the relative balance of influence of these two groups, this view suggests that the EU should consistently strive to improve access to foreign markets for its exporters while protecting domestic sectors threatened by foreign competition. However, in recent years, diffuse interests such as NGOs have increasingly been able to overcome collective action problems, often joining import-competing groups in opposing trade liberalisation (Poletti \& Sicurelli, $2012,2016,2018$ ), and play an important role in EU trade politics (Dür et al., 2020).

However, as argued by Poletti et al. (2021), these views overlook the impact on the politics of trade of the growing integration of the EU's economy within so-called GVCs. The globalisation and fragmentation of trade, production, and distribution centred around GVCs represent one of the most important developments in the contemporary international economy. This development was triggered by the growing reliance of producers in devel- oped countries on the outsourcing of labour-intensive, less value-added operations to low(er) income countries (Eckhardt \& Poletti, 2018). These producers have either directly created foreign subsidiaries or started to source inputs from independent foreign suppliers (Lanz \& Miroudot, 2011). In the former case, production networks are developed and sustained by multinational corporations that feature various types of integration of production facilities located in different jurisdictions into a single corporate structure. Such corporate structures can be "vertically integrated," where firms take ownership of their supply chain partners and internalise the production of parts and components, or "horizontally integrated," where global firms replicate the full production process in different locations (Helpman, 2006). In the latter case, firms systematically rely on foreign products used as components to deliver final products but do not directly establish production facilities abroad, preferring to coordinate buyer-seller interactions through armslength market relationships (Gereffi et al., 2005). Both groups of firms that rely on the income generated by the import of intermediate products are usually referred to as import-dependent firms (Eckhardt \& Poletti, 2016, p. 4). As a result of these processes, the politics of trade in the EU and elsewhere can no longer be described as a case of "exporters vs import-competing industries." Understanding the politics of trade in this changing context requires adding the role of import-dependent firms to the equation (Anderer et al., 2020).

For instance, the trade policy literature has widely noted that import-dependent firms tend to have stronger free-trade preferences than domestic firms operating in the same sector because they are interested in accessing cheap inputs from their affiliates abroad or independent foreign suppliers and are therefore not similarly wary of competition from foreign producers (Anderer et al., 2020; Eckhardt \& Poletti, 2016; Jensen et al., 2015; Yildirim, 2018; Yildirim et al., 2018). This means that import-dependent firms can be expected to strongly support trade arrangements that do not disrupt their ties within GVCs, as well as to oppose trade policies that could bring about higher import costs (Bernard et al., 2012). Moreover, import-dependent firms are usually the largest and most productive firms within a given industry, which suggests that they have at their disposal more resources for lobbying on trade policy (Baccini et al., 2017; Eckhardt \& Poletti, 2018). Import-dependent firms thus not only hold strong free-trade policy preferences, but they are also likely to weigh politically in the EU trade policymaking process. Overall, these arguments suggest that the growing integration of the EU economy in GVCs should make EU trade policy systematically more free-trade oriented due to the growing political role of import-dependent firms and the consequent political weight of pro-trade domestic coalitions (Dür et al., 2020).

The EU has been one of the main drivers of this process of internationalisation of production centred around GVCs (Amador \& di Mauro, 2015; Dür et al., 
2020); today, it is one of the most resilient, active, and encompassing economic players in terms of using foreign products for production and exports (di Mauro et al., 2013). As a result, many works have documented that import-dependent firms have indeed played a crucial role in the politics of trade in the EU by (a) facilitating negotiations of free trade agreements (Anderer et al., 2020; Eckhardt \& Poletti, 2016; Poletti et al., 2021), (b) reducing support for the imposition of anti-dumping measures (Eckhardt, 2013, 2015), and (c) promoting compliance with adverse panel rulings in the WTO dispute settlement (Yildirim, 2018).

The same logic should also be relevant to the political dynamics underpinning the decision to adopt sanctions against Myanmar. The imposition of sanctions would imply eliminating privileges granted under the GSP scheme, which entails removing import duties from products coming into the EU market from a subset of developing countries. Taking into account the role of GVCs and EU import-dependent firms operating within them can help shed light on temporal variation in the EU propensity to adopt sanctions against developing countries. When the EU faces the choice of adopting sanctions with developing countries with which it is weakly integrated into GVCs we should expect domestic political coalitions to be dominated by groups supporting sanctions. For one, we can expect import-dependent firms, backed by NGOs, to support economic sanctions that could reduce their exposure to imports from labourabundant countries. At the same time, the opposing coalition of export-oriented firms is not likely to be strong given that these markets are not particularly interesting for exporters of goods produced in high-cost locations. Conversely, when the EU faces the choice of adopting economic sanctions with developing countries with which it is highly integrated into GVCs, import-dependent firms can be expected to play a significant political role, widening the domestic political coalition opposing the imposition of such sanctions and making it less likely that economic sanctions are adopted.

\section{A Longitudinal Case Study of EU-Myanmar Relations}

In this section, we examine the plausibility of the argument developed so far through a longitudinal analysis of the politics underpinning both the EU's decision to impose economic sanctions against Myanmar by suspending the GSP scheme and the decision to refrain from doing so in the face of the Rohingya crisis in 2018. This longitudinal case study serves our purposes well because it allows us to trace how the EU position evolved in response to changes in the value of our key explanatory factor, i.e., the (absence) presence of import-dependent firms in the domestic politics of the EU. In addition, our empirical research enables us to keep constant and control for important exogenous potential sources of variation such as cultural perceptions, strategic interests, and colonial ties. More specifically, using a combi- nation of congruence testing and process tracing (Dür, 2008; George \& Bennett, 2005), we show that importdependent firms played a limited role in the political discussions preceding the suspension of the GSP scheme before 1997 while they played an active and significant role in the period before 2017 . To carry out our analysis, we triangulate three sets of sources: (a) secondary sources such as media, policy-oriented, and scholarly publications; (b) primary sources such as official documentary records from relevant institutions and policy statements by interest groups and NGOs; and (c) interviews with first-hand participants in the processes under investigation. Moreover, to strengthen the plausibility of our argument, we also briefly discuss the case of the decision of the EU to suspend the GSP in relation to Cambodia in 2020.

Following the case of Myanmar in 1996, the EU suspended or downgraded the GSP in three further cases, namely Belarus (2007), Sri Lanka (2010), and Cambodia (2020). The latter case is more comparable to Myanmar in several respects. Both Myanmar and Cambodia are classified as less developed countries by the UN and are therefore eligible for the EU's Everything but Arms (EBA) scheme, an initiative under the Eu's GSP scheme which provides the least developed countries with duty-free and quota-free imports, except for armaments. The two Southeast Asian countries are labour-abundant countries and members of the Association of South-East Asian Nations (ASEAN). Finally, debate on the possibility of imposing GSP suspension on the two countries took place in the EU at almost the same time, which allows us to dismiss the hypothesis that the EU's decision not to impose GSP suspension in the case of Myanmar was due to concern that it would not be effective. Despite their shared features, the EU refrained from imposing commercial sanctions on Myanmar following the 2017 crisis, while it took a more assertive approach in the case of Cambodia in 2020. The brief discussion of the case of Cambodia allows us to show that, in line with our argument, domestic economic interests affected the EU's sanctioning behaviour.

We are aware that our single case-study approach does not allow for generalisations across other instances of EU sanctioning behaviour. At the same time, we would like to stress that plausibility probes demonstrating the empirical relevance of an argument in the context of one significant case in which it can be concretely applied play a crucial role in the process of theory development, particularly when used as preliminary studies on relatively untested theories and hypotheses such as the one presented in this article (Eckstein, 1975; George \& Bennett, 2005; Levy, 2008).

\section{EU Trade Sanctions on Myanmar's Use of Forced Labour (1997-2013)}

The EU firmly reacted to the authoritarian government established by the military junta in Myanmar in 1988, 
and it did so with multiple foreign policy instruments that culminated in the decision to impose EBA withdrawal in 1997. At the end of the 1990s, Myanmar was not a major destination for European investors and importers, and the prospect of imposing trade sanctions in the form of a suspension of the GSP scheme (which was strongly sponsored by European trade unions) did not raise substantial opposition from European business organisations.

In 1995, a joint complaint of the European Trade Union Confederation and the International Confederation of Free Trade Unions pushed the European Commission to open an investigation against Myanmar, which demonstrated the existence of forced labour in the country (Portela \& Orbie, 2014), and human rights NGOs, led by the International Federation of Human Rights, joined the call for sanctions (European Parliament, 1997a). The investigation involved hearings with NGOs and experts and discovered that forced labour was a widespread practice in infrastructure projects within the country (Portela \& Orbie, 2014). The ILO also established a Commission of Inquiry on forced labour in the country in 1996. The Commission's investigation and the ILO Commission of Inquiry pushed the European Parliament and the European Council to take a stance on the matter. As a result, the European Parliament passed a non-binding resolution calling EU members to end all trade, tourism, and investment ties (18 July 1996; see McCarthy, 2000). In October of the same year, the European Council $(1996,1)$ noted "the absence of progress towards democratisation and at the continuing violation of human rights" and confirmed earlier restrictive measures against Myanmar, such as visa bans and arms embargo.

Pressures from trade unions and human rights NGOs to sanction Myanmar did not face considerable resistance among European exporters or investors. Even though European investments accounted for the majority of foreign direct investments in the country (see Table 1), they still amounted to a limited share of European foreign investments compared to 2017. Furthermore, by the end of 1996, several European firms (including Philips, Carlsberg, Heineken, Interbrew) had left Myanmar, followed by Burton, British High Street, and Ericson in 1997 (Arianayagam \& Sidhu, 2013; Than \& Than, 1997) due to public pressure in their home markets (Speece \& Sann, 1998) and the boycott adopted by US local governments (Guay, 2000; “Heineken to pull out of Burma,2).

The French oil company Total (present in the country since 1992; see Dhooge, 1998) was the main European oil company operating in the country. Nevertheless, Total was not proactive in calling for the EU to take a softer approach on Myanmar because both its operations would not be directly affected by the suspension of the GSP scheme (European Parliament, 1997a), and Total itself had attracted criticism for being involved in forced labour in Myanmar (European Parliament, 1997b). The company denied such allegations and claimed that the country's military junta should rather be held responsible for those crimes (Dhooge, 1998). On the insistence of the so-called like-minded countries (especially Scandinavian countries; see Forster, 2000), the European Council (1998) ultimately approved the EU regulation on GSP withdrawal "on account of the use of forced labour" in 1997, with little dissent among the governments of the 15 EU member states (Speece \& Sann, 1998). For the first time, the EU decided to withdraw GSP privileges to a country due to concerns about labour rights violations, which resulted in many European companies deciding to stop operating in Myanmar (Heiduk, 2020).

In the early 2000s, with the increasing integration of South-East Asian countries in the GVCs, the EU started looking at the region as a strategic trade and investment partner. In this framework, the hypothesis of lifting trade sanctions on Myanmar entered the agenda of European institutions. In 2006, the Global Europe Communication of the European Commission called for a greater investment of European companies in ASEAN to respond to growing competitors in the region, including the US and China. Myanmar became more attractive for EU investors, especially after the reform process launched by President Thein Sein and after the formation

Table 1. FDI in Myanmar by main EU partners (US million \$).

\begin{tabular}{|c|c|c|}
\hline & $\begin{array}{c}1996 \\
\text { (before GSP withdrawal) }\end{array}$ & $\begin{array}{c}\text { 2017-2018 early average } \\
\text { (when EU decided not to impose GSP withdrawal) }\end{array}$ \\
\hline United Kingdom & 1,004 & / (not EU member) \\
\hline France & 465 & 5,199 \\
\hline Netherlands & 237 & 266,961 \\
\hline v Austria & 71 & 932 \\
\hline Germany & 15 & 126,491 \\
\hline v Denmark & 13 & 3,670 \\
\hline v Norway & / & 3,000 \\
\hline Ireland & / & 551 \\
\hline TOTAL & 1,805 & 406,804 \\
\hline
\end{tabular}

Source: our elaboration from Directorate of Investment and Company Administration (n.d.). 
of a partially civilian government. In February 2012, the umbrella association of European business, Business Europe, met several EU officials and lobbied for the lifting of sanctions. A representative of Business Europe's international relations committee, Winand Quaedvlieg, expressed the new interest in the country, claiming that "there is a lot of potential in the country....There is a low level of development and high potential, both in raw materials and in human resources" (Baker, 2012). Human rights groups in Europe warned about the implications of any hasty removal of sanctions ("Europe rushes to lift sanctions," 2012), but, despite there being resistance, the EU opted to phase out sanctions in April 2012 and lifted them all together one year later, with the only exception of the arms embargo (Bünte \& Portela, 2012). The Council declared it was ready to reinstate the GSP to Myanmar, and the European Parliament quickly supported this decision.

Following this decision, Myanmar became an increasingly attractive source of imports into the EU and a destination for European investors (see Figure 1). The EU also promoted parallel diplomatic cooperation with the country and support for the democratic transition. In 2012-2013 the EU increased its development support to Myanmar and opened a delegation to the country (European Commission, 2016). Such cooperation faced a major challenge in 2017 when the Rohingya crisis raised major international attention. As the next section shows, though, the growing economic stakes the EU had developed there reduced the incentive for the EU to opt for commercial sanctions as an instrument for human rights promotion.

\section{EU Softer Reaction to Myanmar's Rohingya Crisis (2017-Present)}

In 2017-2018, when the EU started considering imposing a new GSP withdrawal on Myanmar, it had larger economic interests than in the late 1990s. Despite the international mobilisation against the involvement of the Burmese military in the Rohingya crisis, the EU opted for a softer approach than it had in the late 1990s.

After the return of trade privileges with the EU in July 2013, EU FDI to the country and trade flows increased considerably. From 2014 to 2016, European retailers sourcing apparel from Myanmar became major importers from the country ("EU considers textile trade sanctions," 2018; "EU to boost garment industry," 2019). Germany became Myanmar's fifth trading partner in 2014 (Renwick, 2014). Besides, European companies heavily invested in Myanmar in the oil, gas, and tourism sectors. In 2017-2018 Myanmar's exports to the EU amounted to 1.56 billion euros (\$1.81 billion), approximately ten times the value of its exports in 2012 (Emmott \& Blenkinsop, 2018). In 2018, the EU was a major source of FDI in Myanmar and the sixth trading partner of the country (Emmott \& Blenkinsop, 2018). Table 1 shows that in 2017-2018 FDI to Myanmar from the major European trade partners amounted to an average of US $\$ 406.804$ million per year, in contrast to US \$1.805 million in 1996.

Following the mass violence involving the Burmese military against the Rohingya minority in 2017, a debate originated within the EU on the option of once again imposing EBA withdrawal on Myanmar. In contrast to

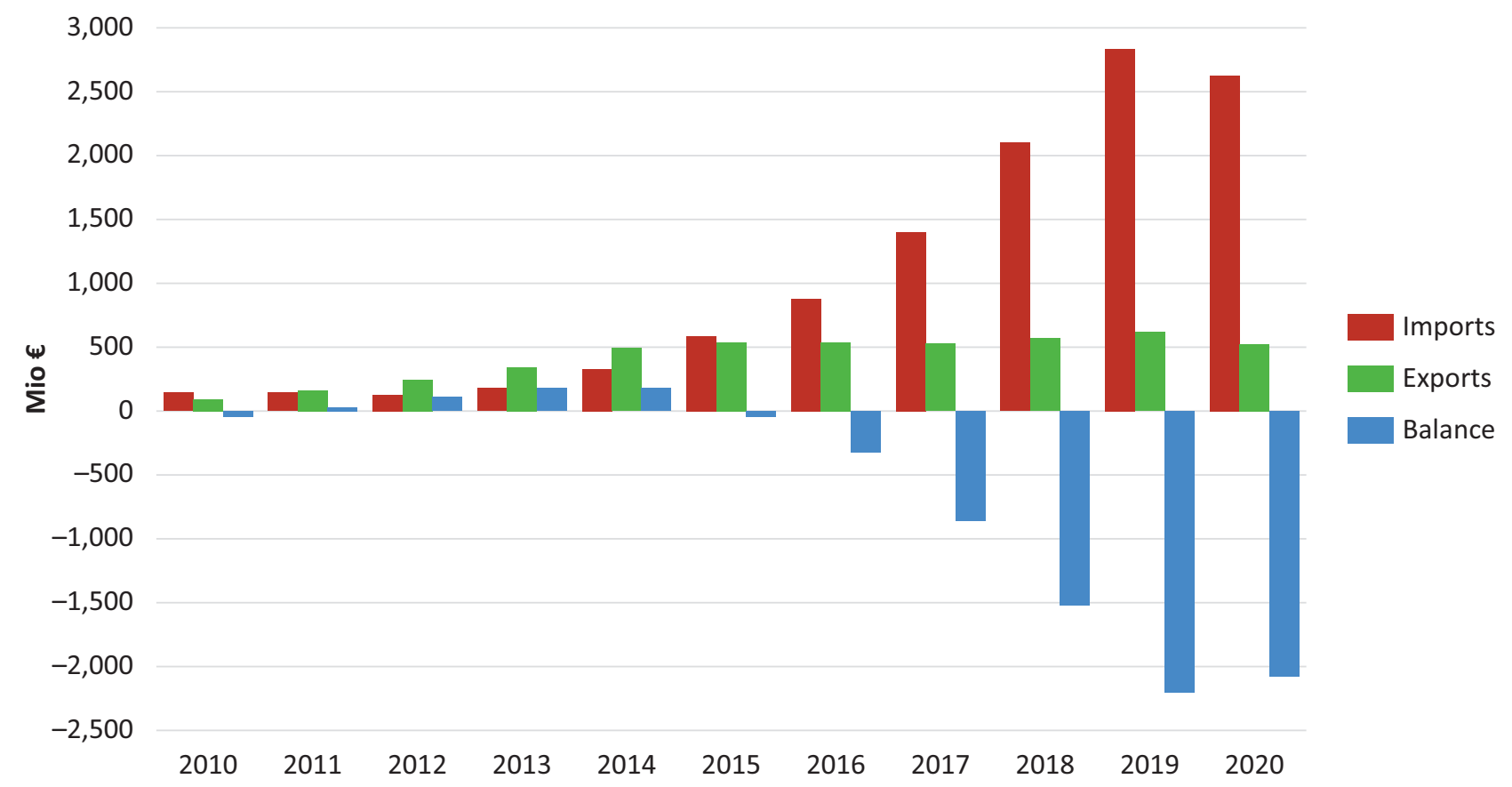

Figure 1. EU trade flows with Myanmar (imports to the EU, exports from the EU, and balance), annual data 2010-2020. Source: European Commission (2021). 
the previous stage, in 2017 and 2018, echoing the growing international scepticism regarding the effectiveness of comprehensive sanctions, NGOs adopted more cautious positions than in the 1990s on the prospect of imposing such a measure (Amnesty International, 2017; European Burma Network, 2018; Human Rights Watch, 2017), while at the same time recognising the lack of success of targeted EU sanctions in putting an end to the use of violence by the Burmese military ("EU considers textile trade sanctions," 2018). More explicit positions in favour of GSP withdrawal came from protectionist groups in the EU member states especially hit by the economic consequences of importing cheap products from Myanmar. The Italian agricultural organisation Coldiretti (2018), for instance, firmly pushed the European Commission to impose trade sanctions on Myanmar due to its concerns regarding human rights violations.

The European Parliament was the most vocal European institution calling for a firm reaction to the Rohingya crisis. Besides NGOs' concerns about the lack of targeted sanctions and protectionist pressures, the European Parliament considered imposing new trade sanctions due to the salience of the Rohingya crisis for the European public and the recognition of the limited effect of development cooperation efforts in the country (Meissner, 2021). Thus, in 2018 the European Parliament asked for a new investigation on Myanmar, followed by a call for GSP withdrawal ("EU considers textile trade sanctions," 2018).

At this stage, this proposal was met with strong resistance by the European business sector. European retailers such as AVE trade association of German Retailers ("EU to Cambodia," 2018), H\&M ("Brands mull Myanmar sourcing," 2019), the C\&A foundation (Reed, 2018), argued against GSP withdrawal, claiming that such a sanction would not harm the military and would have a negative impact upon Burmese workers. The latter mainly include young women, $20 \%$ of whom come from the Rakhine state, where the crackdown of the Rohingya crisis occurred. Moreover, in contrast to what happened in the 1990s, the European retailer association did not respond to consumers' concerns over human rights violations in Myanmar. European companies (including H\&M, Benetton, and Primark) waited until the military coup in 2021 before freezing imports. Similarly, the executive director of the European Chamber of Commerce in Myanmar, Filip Lauwerysen, commented that "a withdrawal will not only risk a slowdown, or even a stop of current capacity building activities [in the garment industry], but most likely close the potential for new interventions" (Heijmans, 2019). Business Europe (interviewed May 2021) further elaborated on this position. The increasing attractiveness of the ASEAN region for European retailers has represented an incentive for the mobilisation of stakeholders against GSP withdrawal. More specifically, according to Business Europe, GSP withdrawal should be a last resort measure; it should be based on uncontroversial empirical evidence of the human rights violations perpetrated by the target government and supported by clear information of the EU's evaluation criteria and the steps required to reinstate the GSP.

As a response to these pressures, the European Commission discussed the option of imposing sectorspecific EBA withdrawal and considered the option of exempting textiles from EU trade sanctions. According to an EU official, though, given the size of the lucrative sector in Myanmar (which makes up more than $75 \%$ of Myanmar's exports to the EU), that would have clearly reduced the impact of EU sanctions ("EU considers textile trade sanctions," 2018). In October 2018, the EU delegation met with representatives of Burmese stakeholders in Yangon to discuss the implications of the preferential trade agreement. The mission findings would also help the EU to determine the implications of a possible EBA withdrawal (Centro de Información sobre Empresas y Derechos Humanos, 2018).

EU institutions also endorsed European foreign investors' requests, opting not to impose the GSP based on similar arguments to those proposed by European retailers (as per informal conversation with EU staff). More explicitly, they declared their concern for the fact that "the formal threat of losing tariff-free access would quickly hit foreign investment in the apparel industry, where European manufacturers take advantage of relatively low labour costs in Myanmar" ("EU considers textile trade sanctions," 2018). According to an EU official, imposing trade sanctions would strengthen Chinese trade relations with Myanmar ("EU considers textile trade sanctions," 2018). Finally, the EU opted not to impose EBA withdrawal, considering that they "are concerned about the impact on the population from our potential measures" ("EU considers textile trade sanctions," 2018).

In 2019 the EU became the third largest trade partner of Myanmar (China and Thailand being the first and second, respectively), accounting for $11 \%$ of total Burmese trade. The EU imported goods worth $€ 2.8$ billion from Myanmar, mainly including textiles, footwear, and agricultural products (European Commission, 2020). A representative of the EU delegation in Myanmar also commented on the greater interests of European importers and investors in the country compared to the 1996-1997 period.

\section{A Further Probe: EU Relations With Cambodia}

The evolution of EU relations with Cambodia further supports our argument. Indeed, a parallel debate on EBA withdrawal took place in the EU in relation to Cambodia due to concerns about violations of labour rights in the country. In this case, the EU ultimately opted to partially withdraw EBA in August 2020, which raised doubts of lack of consistency in EU trade and human rights relations with different countries.

Although the Myanmar ethnic cleansing raised more serious concern in Europe than Cambodia's violations 
of labour rights, the High Representative of the Union for Foreign Affairs and Security Policy (2020) ultimately claimed that "the EU will continue its active engagement with the Government of Myanmar including within the EBA enhanced engagement." In line with our argument, the country director of the Konrad-Adenauer-Stiftung Cambodia, Daniel Schmücking, explained this apparent inconsistency in European external relations by claiming that the EU had opted for EBA withdrawal in Cambodia as the result of limited European interests concerning trade relations (Schmücking, 2020). As a matter of fact, in contrast to Myanmar, it appeared clear that Cambodia has chosen to bandwagon with China with respect to its trade relations (Po \& Primiano, 2020). In 2019, Cambodia and China launched negotiations for a free trade agreement and reached a deal in October 2020. Myanmar, on the other hand, has developed a more cooperative relationship with the EU since 2013 , epitomised by the launch of negotiations towards a free trade deal with the EU in that year. Such an openness to trade negotiations with the EU has contributed to European institutions becoming more sensitive to pressure from stakeholders who wish to preserve trade relations.

\section{Conclusion}

The comparison between the EU's decisions to impose GSP suspension in its relations with Myanmar in 1996 and the reluctance of the EU to reinstate such a sanction following the 2017 Rohingya crisis show that IPE motivations have contributed to the softening of the European approach to their human rights violations. The increasing integration of ASEAN in the GVC in the last two decades has altered the interests of European investors and retailers who have begun to consider the region an attractive partner. Data concerning the volume of investments of European companies in Myanmar and the launch of trade negotiations with the country in 2013 confirm the increasing interest in the region. While in 1996, European retailers and investors withdrew from the country following accusations that the military junta were ignoring the use of forced labour, two decades later, they actively mobilised to promote a softer approach toward the military there being involved in the Rohingya genocide. As interviews and press sources confirm, despite the context of global attention on the human rights violations in Myanmar, European institutions proved themselves to be responsive to pressure from European investors and retailers when they opted not to withdraw the GSP.

The coup d'état in February 2021 and the mass protest in Myanmar brought the country to the edge of what seems to be an enduring low-intensity civil war. The instability that followed has made once again the country less attractive for European investors and retailers who are now considering leaving the country. This change will probably affect the positions of European stakeholders on Myanmar in the near future and, therefore, of the EU concerning the suspension of the GSP. Following the coup, a joint resolution of European Parliament's members (European Parliament, 2021) re-opened the debate on whether to impose GSP withdrawal on Myanmar and urged the Commission to launch an investigation to suspend trade preferences toward Myanmar, especially in those sectors benefiting companies owned by members of the military.

\section{Conflict of Interests}

The authors declare no conflict of interest.

\section{References}

Amador, J., \& di Mauro, F. (2015). The age of global value chains: Maps and policy issues. Centre for Economic Policy Research.

Amnesty International. (2017, September 27). Myanmar: UN Security Council must impose arms embargo [Press release]. https://www.amnesty.org/en/latest/ news/2017/09/myanmar-un-security-council-mustimpose-arms-embargo

Anderer, C., Dür, A., \& Lechner, L. (2020). Trade policy in a "GVC world": Multinational corporations and trade liberalization. Business and Politics, 22(4), 639-666.

Arianayagam, S. M., \& Sidhu, J. S. (2013). Modern slavery: State-induced forced labour in Myanmar (Burma) and reactions from the international community. MJIR/Malaysian Journal of International Relations, 1(1), 80-97.

Baccini, L., Pinto, P., \& Weymouth, S. (2017). The distributional consequences of preferential trade liberalization: Firm-level evidence. International Organization, 71(2), 373-395.

Baker, L. (2012, March 30). Europe rushes to lift sanctions yoke from Myanmar. Reuters. https://www. reuters.com/article/eu-myanmar-sanctionsidUSL6E8ETA7Q20120330

Bernard, A. B., Bradford-Jensen, J., Redding, S. J., \& Schott, P. K. (2012). The empirics of firm heterogeneity and international trade. Annual Review of Economics, 4(1), 283-313.

Brands mull Myanmar sourcing after military links exposed. (2019, August 28). MarketLine NewsWire.

Bünte, M., \& Portela, C. (2012, July 18). The phased suspension of the EU's targeted sanctions against Myanmar is a test case for future sanction regimes. LSE: European Politics and Policy Blog. http://eprints.Ise. ac.uk/46142/1/blogs.Ise.ac.uk-The_phased_ suspension_of_the_EUs_targeted_sanctions_ against_Myanmar_is_a_test_case_for_future_ sanctio.pdf

Centro de Información sobre Empresas y Derechos Humanos. (2018, October 28). Myanmar: Labor orgs call on EU to reconsider trade privileges withdrawal; loss of jobs \& factory shutdowns feared [Press release]. https://www.business-humanrights.org/ 
es/\%C3\%BAltimas-noticias/myanmar-labor-orgscall-on-eu-to-reconsider-trade-privilegeswithdrawal-loss-of-jobs-factory-shutdowns-feared

Coldiretti. (2018, November 19). UE: Nasce l'alleanza per lo stop al riso importato dall'Asia [EU: The new alliance to stop imported rice from Asia] [Press release]. https://giovanimpresa.coldiretti.it/notizie/ attualita/pub/ue-nasce-lallenza-per-lo-stop-al-risoimportato-dallasia

Dhooge, L. J. (1998). A close shave in Burma: Unocal corporation and private enterprise liability for international human rights violations. North Carolina Journal of International Law, 24(1), 1-69.

di Mauro, F., Plamper H., \& Stehrer, R. (2013). Global value chains: A case for Europe to cheer up (Policy Brief). COMPNET.

Directorate of Investment and Company Administration. (n.d.). Foreign investment by country [Data set]. https://www.dica.gov.mm/en/taxonomy/term/38

Dür, A. (2008). Bringing economic interests back into the study of EU trade policymaking. British Journal of Politics and International Relations, 10(1), 27-45.

Dür, A., Eckhardt, J., \& Poletti, A. (2020). Global value chains, the anti-globalization backlash, and EU trade policy: A research agenda. Journal of European Public Policy, 27(6), 944-956.

Eckhardt, J. (2013). EU unilateral trade policy-making: What role for import-dependent firms? Journal of Common Market Studies, 51(6), 1089-1105.

Eckhardt, J. (2015). Business lobbying and trade governance: The case of EU-China relations. Palgrave Macmillan.

Eckhardt, J., \& Poletti, A. (2016). Trading with Asia: Import-dependent firms and EU-Asia trade agreements. Journal of European Public Policy, 3(10), 1543-1562.

Eckhardt, J., \& Poletti, A. (2018). Introduction: Bringing institutions back in the study of global value chains. Global Policy, 9(S2), 5-11.

Eckstein, H. (1975). Case studies and theory in political science. In F. Greenstein \& N. Polsby (Eds.), Handbook of political science (pp. 73-138). AddisonWesley.

Emmott, R., \& Blenkinsop, P. (2018, October 3). Exclusive: EU considers trade sanctions on Myanmar over Rohingya crisis. Reuters. https://www.reuters.com/ article/us-myanmar-rohingya-eu-exclusiveidUSKCN1MD28E

EU considers textile trade sanctions on Myanmar over Rohingya crisis. (2018, October 3). Reuters. https://www.reuters.com/article/us-myanmarrohingya-eu-exclusive-idUSKCN1MD28E

EU to boost garment industry in Myanmar. (2019, December 9). The Myanmar Times. https://www. mmtimes.com/news/eu-boost-garment-industrymyanmar.html

EU to Cambodia: Fix human rights or face economic hardship. (2018, November 14). Thai News Service.
Europe rushes to lift sanctions yoke from Myanmar. (2012, March 30). Reuters. https://www.reuters. com/article/eu-myanmar-sanctions-idUSL6E8ETA 7Q20120330

European Burma Network. (2018, October 10). Statement from members and observers of the European Burma Network [Press release]. https://burma campaign.org.uk/eu-trade-commissioner-ceciliamalmstrom-must-drop-proposal-to-remove-burmatrade-privileges

European Commission. (2016, June 1). The European Union and Myanmar: A special partnership for democracy, peace and prosperity [Press release]. https://ec.europa.eu/commission/presscorner/ detail/it/MEMO_16_2010

European Commission. (2020). Myanmar(Burma). https://ec.europa.eu/trade/policy/countriesand-regions/countries/myanmar/\#: :text=The\% 20EU\%20ranked\%20as\%20the,\%E2\%82\%AC2.8\% 20billion\%20from\%20Myanmar

European Commission. (2021). European Union, trade in goods with Myanmar. https://webgate.ec.europa. eu/isdb_results/factsheets/country/details_ myanmar_en.pdf

European Council. (1996). Joint Action of 28 October 1996 adopted by the Council on the basis of Article K.3 of the Treaty on European Union, on a programme of incentives and exchanges for legal practitioners ("Grotius").

European Council. (1998). Regulation 2820/98 applying a multiannual scheme of generalised tariff preferences for the period $1 \mathrm{July} 1999$ to 31 December 2001.

European Parliament. (1997a). Report of the Committee on Foreign Affairs, Security and Defence Policy, on the proposal for a Council Regulation (EC) temporarily withdrawing access to generalized tariff preferences for industrial goods from the Union of Myanmar (COM(96)0711-C4-0085/9796/0317(CNS)). https://www.europarl.europa.eu/ doceo/document/A-4-1997-0085_EN.html

European Parliament. (1997b). Withdrawal of GSP from Myanmar: Debates. https://www.europarl.europa. eu/doceo/document/CRE-4-1997-03-13-ITM-011_ EN.html

European Parliament. (2021). Joint motion for a resolution pursuant to Rule 132(2) and (4) of the Rules of Procedure. https://www.europarl.europa.eu/doceo/ document/RC-9-2021-0116_EN.html

Forster, A. (2000). Evaluating the EU-ASEM relationship: A negotiated order approach. Journal of European Public Policy, 7(5), 787-805.

George, A., \& Bennett, A. (2005). Case studies and theory development in the social sciences. MIT Press.

Gereffi, G., Humphrey, J., \& Sturgeon, T. (2005). The governance of global value chains. Review of International Political Economy, 12(1), 78-104.

Giumelli, F. (2017). The redistributive impact of restrictive measures on EU members: Winners and losers 
from imposing sanctions on Russia. Journal of Common Market Studies, 55(5), 1062-1080.

Giumelli, F., \& Ivan, P. (2013). The effectiveness of EU sanctions (EPC Issue Paper No. 76). EPC.

Guay, T. (2000). Local government and global politics: The implications of Massachusetts' "Burma Law." Political Science Quarterly, 115(3), 353-376.

Heiduk, F. (2020). From Pariah image to partner and back again: The EU's complicated relationship with Myanmar. Journal of Asian Security and International Affairs, 7(3), 349-369.

Heijmans, P. (2019, January 31). Sanctions squeeze Myanmar's economy. US News. https://www. usnews.com/news/best-countries/articles/201901-31/western-sanctions-squeezing-myanmarseconomy

Heineken to pull out of Burma. (1996, July 10). Apnews. https://apnews.com/article/bade4a9a63a40daf8f5 eccae0c8c96fd

Helpman, E. (2006). Trade, FDI, and the organization of firms. Journal of Economic Literature, 44(3), 589-630.

High Representative of the Union for Foreign Affairs and Security Policy. (2020). Report on EU enhanced engagement with three Everything but Arms beneficiary countries: Bangladesh, Cambodia and Myanmar-Accompanying the document "Joint report to the European Parliament and the Council report on the generalised scheme of preferences covering the period 2018-2019" (SWD(2020) 19 final). https://eur-lex.europa.eu/legal-content/NL/TXT/ ?uri=CELEX:52020SC0019

Human Rights Watch. (2017, September 17). Burma: Targeted sanctions, arms embargo needed [Press release]. https://www.hrw.org/news/2017/09/17/ burma-targeted-sanctions-arms-embargo-needed

Jensen, J. B., Quinn, D. P., \& Weymouth, S. (2015). The influence of firm global supply chains and foreign currency undervaluations on US trade disputes. International Organization, 69(4), 913-947.

Lanz, R., \& Miroudot, S. (2011). Intra-firm trade: Patterns, determinants and policy implications. OECD Publishing.

Levy, J. (2008). Case studies: Type, designs and logics of inference. Conflict Management and Peace Science, 5(1), 1-18.

McCarthy, S. (2000). Ten years of chaos in Burma: Foreign investment and economic liberalization under the SLORC-SPDC, 1988 to 1998. Pacific Affairs, 73(2), 233-262.

Meissner, K. L. (2021). Requesting trade sanctions? The European Parliament and the generalized scheme of preferences. JCMS: Journal of Common Market Studies, 59(1), 91-107.

Po, S., \& Primiano, C. B. (2020). An "ironclad friend": Explaining Cambodia's bandwagoning policy towards
China. Journal of Current Southeast Asian Affairs, 39(3), 444-464.

Poletti, A., \& Sicurelli, D. (2012). The EU as promoter of environmental norms in the Doha round. West European Politics, 35(4), 911-932. vPoletti, A., \& Sicurelli, D. (2016). The European Union, preferential trade agreements, and the international regulation of sustainable biofuels. Journal of Common Market Studies, 54(2), 249-266.

Poletti, A., \& Sicurelli, D. (2018). The political economy of normative trade power Europe. Palgrave Macmillan.

Poletti, A., Sicurelli, D., \& Yildirim, A. B. (2021). Promoting sustainable development through trade? EU trade agreements and global value chains. Italian Political Science Review/Rivista Italiana Di Scienza Politica, 51(3), 339-354. https://doi.org/10.1017/ ipo. 2020.33

Portela, C., \& Orbie, J. (2014). Sanctions under the EU generalised system of preferences and foreign policy: Coherence by accident? Contemporary Politics, 20(1), 63-76.

Reed, J. (2018, October 19). EU urged to keep Myanmar trade preferences; Rohingya rights. Financial Times. https://www.ft.com

Renwick, N. (2014). China's role in Burma's development. IDS Bulletin, 45(4), 70-84.

Schmücking, D. (2020). Why Cambodia? EU's incoherence in trade preferences under the EBA scheme (Konrad-Adenauer-Stiftung Report). Foundation Office Cambodia. https://www.kas.de/en/web/ kambodscha/single-title/-/content/why-cambodiaeu-s-incoherence-in-trade-preferences-under-theeba-scheme-3

SIPRI. (2021, June 17). EU arms embargo on Myanmar (Burma) [Press Release]. Stockholm International Peace Research Institute.

Speece, M., \& Sann, P. (1998). Conflict in manufacturing joint ventures in Myanmar. Journal of Euro Asian Management, 4(3), 19-43.

Staunton, E., \& Ralph, J. (2020). The responsibility to protect norm cluster and the challenge of atrocity prevention: An analysis of the European Union's strategy in Myanmar. European Journal of International Relations, 26(3), 660-686.

Than, T. M. M., \& Than, M. (1997). Myanmar: Economic growth in the shadow of political constraints. Southeast Asian Affairs. https://www.jstor.org/stable/ 27912179

Yildirim, A. (2018). Domestic political implications of global value chains: Explaining EU responses to litigation at the World Trade Organization. Comparative European Politics, 16, 549-580.

Yildirim, A. B., Poletti, A., Chatagnier, T., \& De Bievre, D. (2018). Internationalization of production and the politics of compliance in WTO disputes. Review of International Organizations, 13(1), 49-75. 


\section{About the Authors}

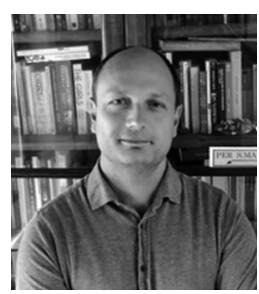

Arlo Poletti has been an associate professor of international political economy at the Department of Sociology and Social Research of the University of Trento since 2016. He obtained a PhD from the University of Bologna, was a post-doctoral researcher at the University of Antwerp, and held positions as an assistant professor at the LUISS Guido Carli and the University of Bologna. His research focuses on the political-economy globalisation with particular emphasis on the politics trade policy-making, interest group politics, and individual-level political behaviour.

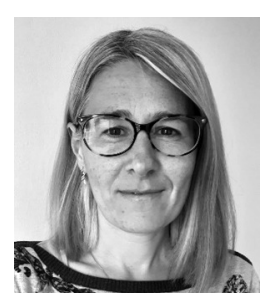

Daniela Sicurelli is an associate professor of international relations at the Department of Sociology and Social Research at the University of Trento. Her research interests include European external relations, development cooperation, and international norm promotion. 